Portland State University

PDXScholar

Women, Gender, and Sexuality Studies Faculty

Publications and Presentations

Women, Gender, and Sexuality Studies

2011

\title{
The Obvious Invisibility of the Relationship between Technology and Social Values
}

Jamie P. Ross

Portland State University, rossj@pdx.edu

Follow this and additional works at: https://pdxscholar.library.pdx.edu/wgss_fac

Part of the Communication Technology and New Media Commons, Philosophy Commons, and the Science and Technology Studies Commons

Let us know how access to this document benefits you.

\section{Citation Details}

Ross, J. P. (2011). The Obvious Invisibility of the Relationship between Technology and Social Values. International Journal of Science In Society, 2(1), 51-61.

This Article is brought to you for free and open access. It has been accepted for inclusion in Women, Gender, and Sexuality Studies Faculty Publications and Presentations by an authorized administrator of PDXScholar. Please contact us if we can make this document more accessible: pdxscholar@pdx.edu. 


\title{
The Obvious Invisibility of the Relationship between Technology and Social Values
}

\author{
Jamie P. Ross, Portland State University, Oregon, USA
}

\begin{abstract}
We all too often assume that technology is the product of objective scientific research and that technology's moral value lies in only the moral character of its user. To remove technology from a moral realm, we assume value and context neutrality. Yet the power of technology is a reflection of the values that exist in its developmental context. Technology's moral realm is visible in the reciprocal relationship between culture and technology in the epidemiology of AIDS, clinical research and practice regarding heart disease, and DNA research. Cultural values decide what counts as a scientific question. When we look at the 1980s epidemiological model for AIDS, we see how the presuppositions within a culture frame the type of question asked; that is "In what population does AIDS occur?" This question initially leads scientific research away from individual behavior until a different question is asked. Secondly, that which constitutes a scientific problem in turn directs the kinds of technologies developed. Men who were dying of heart disease showed symptoms in large arteries of the heart when using technologies designed to find these symptoms. Women were also dying of heart disease, but because the large arteries were not overwhelmingly compromised, women were not properly diagnosed until recently. If large arteries are the "problem," seeing smaller vessels as problematic is more difficult. If the cultural standard of the healthy body is a male body, technologies responsive to that body are developed. Thirdly, a type of technology developed will in turn create new or enhanced values. A biological/genetic basis for race or intelligence is a scientific answer to a culturally defined problem, and the cultural issue of race is defined as problematic by scientific fact. Technology directs human values and behaviors in predictable ways; thus, technologies are ethically valenced.
\end{abstract}

Keywords: Technology, Cultural Values, Invisibility

$\mathrm{A}$

LL TOO OFTEN, we assume that technology is the product of objective scientific research, and we assume that technology's moral value lies only in the moral character of its user. It is true that technology has no inherent moral agency; humans can be judged good or bad and their actions right or wrong. Yet in order to objectify technology in a manner that removes it from the moral realm, we rely on the assumption that technology is value neutral; that is, it is independent of all contexts other than the context in which it is used. The belief that technology is simply a tool, to be used in certain moral or immoral ways, rests on a utilitarian ontology, one that holds no inherent value. However, there is a power to technology, and some would go so far as to suggest that in many instances technology assumes an autonomous nature. ${ }^{1}$ At the very least, technology should be seen as reflecting the values from which it arises: a developmental context. Technology does have an inherent nature; a nature that has motivational energy. Consequently, as we investigate the relationships between culture and technology by looking at the epidemiology of AIDS,

\footnotetext{
${ }^{1}$ J. Ellul, The Technological Society, trans. J. Wilkenson (New York: Knopf, 1964)

The International Journal of Science in Society

Volume 2, Number 1, 2011, http://science-society.com/journal/, ISSN 1836-6236

(C) Common Ground, Jamie P. Ross, All Rights Reserved, Permissions:

cg-support@commongroundpublishing.com
} 
clinical research and practice regarding heart disease, and DNA research, we can make the invisible moral realm visible.

We are frequently naive regarding the valences (that is, the tendencies) of technology. These tendencies, as Corlan Gee Bush defines in her article, "Women and the Assessment of Technology," comprise an inherent ontological nature of technology. In other words, we often do not notice the collective concepts imbedded in the technologies that direct human action. These technologies are filled with the ideas of a culture, or of many cultures. They encompass the values of a culture, and as technologies emerge out of those values, they further enhance or create new values that direct human behavior, and in turn, these values direct new technologies.

According to Bush, the propensity for tools to function in certain ways in certain settings is a "valence." Like electrons around the nucleus of a cell, technologies tend "to be favored in certain situations, tend to perform in a predictable manner in these situations, and tend to bend other interactions to them." 2 Technologies tend to seek out or fit in with certain social norms and to ignore or disturb others. Technologies may be comprised of tools, but they are not simply tools; as tools engage techniques, they present powerful organized systems of thought and language that direct human action.

Alternatively, in Technopoly, Neil Postman suggests that "invisible technologies," are organized systems that have inherent influence and can seem invisible. He offers language as an example of a hidden technology. Metaphor, for example, influences how we think and act. Language not only directs our behavior in the most obvious of ways (such as, "Don't forget your coat") but also directs it in more subtle ways that influence, and may even coerce, human action without conscious recognition. "Unlike television or the computer, language appears to be not an extension of our powers but simply a natural expression of whom and what we are. This is the great secret of language: Because it comes from inside us, we believe it to be a direct, unedited, unbiased apolitical expression of how the world really is." 3 The suggestion is that even those entities that we would not consider technology in our ordinary understanding may be technology nonetheless. This observation sensitizes us to the subtle ways in which a technology can reflect cultural priorities and influence our thoughts and behavior.

The valence of computer software can be made visible. Software, like spoken language, is a reflection of thought, as well as that which gives direction to thought. Our recognition of valences in technologies, particularly in invisible technologies, offers evidence to a claim that technology is not value neutral. Consequently, the subjective nature of technology lends itself to a moral analysis far beyond the limited realm of the user's moral character and the particular use to which the technology is put.

Yet as we normalize the use of technology, we sometimes render invisible those social values that nudge technology's development. We render invisible a collective social responsibility. The developmental, the cultural, and the environmental contexts that Bush claims are always at work, and are those arenas that coordinate the mixture out of which technologies emerge. Our inattention to the context out of which our technological creativity emerges al-

\footnotetext{
${ }^{2}$ Corlan Gee Bush, "Women and the Assessment of Technology," in Society, Ethics and Technology, ed. Morton E. Winston and Ralph D. Edelbach (California: Wadsworth, 2000), 72-3.

${ }^{3}$ Neil Postman (1992) "Invisible Technologies," in Society, Ethics and Technology, ed. Morton E. Winston and Ralph D. Edelbach (California: Wadsworth, 2000), 124-5.
} 
lows us to think of scientific and technological research, as well as medicine and medical research, as value neutral, objective, independent of cultural values, and free of the influential capacities we often attribute to human agency.

The classic philosophic dichotomy that stabilizes such a view is the fact/value problem: cultures exhibit values; scientific technology rests on hard facts. Yet, as John Dewey so aptly suggests, we should move past the philosophic dichotomies that create and support such claims rather than treating them as problems to be solved. ${ }^{4}$ The articulation of a problem that separates culture from technology is a false dichotomy. There is little or no independence between culture and technology to suggest that values lie only in the realm of culture and hard facts remain only in the realm of technology.

Our limited ability to notice the interdependence of culture and technology rests on our resistance to making the developmental contexts out of which technology rises visible, as well as on the cultural, environmental, and user contexts that technology influences. And, as any readers of Dewey will remember, one of the biggest problems of philosophy, as it plays out in everyday experience, is the absence of context. ${ }^{5}$

Because of a limited ability to notice that which we are accustomed to, we fail to pay adequate attention to the varied contexts out of which technology emerges and influences. The normalization process, as previously mentioned regarding language as a technology, makes the visibility of technology's valence or influence more difficult to notice. Thus we assume the objective nature of technology. Without context (that is, the notion of a collective social responsibility) we tend to disengage ourselves from any moral debate as to either the development or effects of technology within the lab. The ethics of technology becomes a subject that creates only conversations about if, how, and when a particular form of technology should be used, and by whom. Technological progress focuses only on what tools do the job well, not on what questions the tools are a response to.

In the process of objectifying technology, we remove the variable, unpredictable, and precarious dimensions of its nature. In the name of serving mankind, we strip it to its objective components and ask only those questions that reflect our interests. When technology does not appear to serve mankind, we hold only the user responsible, for his or her actions are the only patterns or systems made obvious.

Valence is an invisible form of social control. The mechanics of such control are articulated by Stephen Jay Gould in The Mismeasure of Man. He warns us of the process by which we reify, rank, and objectify qualitative dimensions of life. The process by which we change qualitative dimensions of life into quantitative measures, rank them on a hierarchical value scale, and separate them from having a kind of value laden agency, predisposes all analysis to only functional use; that is, solving current problems in moral ways. The moral predisposition of technology remains invisible.

This is not to say that technology is somehow independent of the humans who create and use it. It is not to suggest that inanimate objects have a life of their own and, as animate objects do, exert power over people and other things. It is not to anthropomorphize technology in the way we anthropomorphize computers. Valence is not to be understood as a power to

\footnotetext{
${ }^{4}$ John Dewey (1927), "The Public and its Problems" in John Dewey: The Later Works, 1925-1953, ed. Jo Ann Boylston (Carbondale and Edwardsville, IL: Southern Illinois University Press, 1981-90), 3 (hereafter cited as LW).

5 John Dewey (1931), “Context and Thought,” LW 6: 5-6.
} 
control outcomes. Valence is the tendency of technology to be used in certain ways because of both the social values out of which it arises and the values it tends to foster. See figure 1.
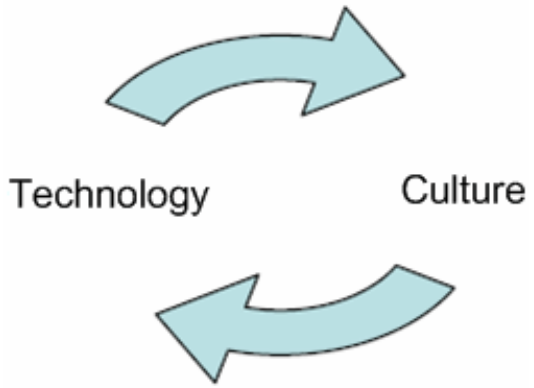

Figure 1

This suggests that we are not in complete control of technology's development, creation, use, and environmental impact. We know that we lack total control, but we do not have a total lack of control. Technology maintains a form of control over social affairs when we are lulled into believing we can make little difference. This happens when, as Bush suggests, we believe there is nothing wrong that cannot be fixed by technology, and so we do nothing. Alternatively, when those who fear the momentum of technology are frightened into passivity, and we do nothing, technology gains control over us. ${ }^{6}$ This is the extent to which technology's valence controls human action. Thus valence can be understood as both the momentum technology accumulates, which curtails human interaction and intervention, and the potential or propensity for that technology's use in particular manners. The second notion fails to recognize the value dimension of technology. And, although the first notion subtly acknowledges that technology is not value neutral, we shy away from acting on this suspicion.

\section{Historical Example of Valenced Technology in Railroad Track Gauge Uniformity}

As we analyze the complexity of the relationship between technology and social values, we may begin to appreciate the importance of making the invisible visible. Historically, for example, Ruth Schwartz Cowen traces and correlates efficiency and uniformity, the working values of corporate management, to the standardization of railroad track gauge in the late $1890 \mathrm{~s}$. The goal of standardizing rail gauge required the technology of integrated, efficient, and uniform corporate takeovers of the telegraph, telephone, and petroleum industries. Standardization of technology and human resources represented the working values. The technology of uniform rail gauges was imbued with cultural values.

The uniformity of the rail gauge was not simply a value neutral tool that enabled the rapid movement of goods around the country. It was an answer to one of many questions: "How do we coordinate human beings in an efficient and uniform mode for the efficient and uniform transportation of goods?" As such, the rail gauge incorporated much more than a simple utilitarian function. While single gauge rails may have been the tool, their standardization also presented a technology whose valence was directed toward social control, and whose

\footnotetext{
${ }^{6}$ Bush, "Assessment of Technology," 73.
} 
values of efficiency and uniformity emanated from a particular cultural context of competition. While the moral legitimacy of competitive capitalism as the basis for a healthy economy has been debated in the past, from Karl Marx to Max Horkeimer, and on into contemporary times, the values of efficiency and uniformity have nevertheless acted as the systematic momentum for the development of technology in many forms, from railroads to department stores and advertising to email. In each case, however, were we to notice that these were the values at work developing railroads, department stores, advertising, and email, we would not be debating their ethical value based solely on who they are used by and how they are used. We would have to make visible the fact that these individuals or groups of people were working within a context whose emphasis on competitive practice drove them to develop these innovations. At the same time, we would notice that there are cultural and environmental consequences that do not map uniformly for the betterment of mankind, but rather work toward the betterment and detriment of particular individuals and groups of individuals.

A moral evaluation of self-interest is but one dimension of analysis; another involves technology's propensity toward emphasizing and reflecting certain values, which then predispose individuals and groups to highlight these values. The extent to which individual behavior is directed (although this is not to suggest that individuals are not moral agents in and of themselves) is also the extent to which technologies, arising out of certain sets of values, foster the further development of technologies that reflect similar values.

\section{Conceptual Example of the Circular Relationship between Social Values and Technology in Language and Metaphor}

This example engages a metaphysical philosophy of language perspective as it relates to how we think about the world and our place in it. Metaphors reflect culture. ${ }^{7}$ Over a period of time that spans from the late enlightenment period of the seventeenth century to the late industrial period of the nineteenth century, we experienced a shift in view from a consideration of the world as an organic or live entity to a consideration of the world as a metaphorically inanimate and mechanical entity. ${ }^{8}$ When we shifted our view of the world from that of the earth as something comprising the complexities of live, interdependent ecological systems to a view of the earth as something inanimate and independent, with compartmentalized systems, our practices (technologies) shifted as well.

The mechanization of the environment over a long period of time emerged as a justification for freeing the earth for commercial activity. Our dominion over the earth stemmed from divine command: "God, who hath given the world to men in common, hath also given them reason to make use of it to the best advantage of life and convenience." 9 Thus a unique sense of moral power emerged that subordinated the environment to human will. Efforts were made to have the earth reveal her secrets. ${ }^{10}$ The belief in man's moral dominion over the earth enabled the "earth as machine" metaphor to thrive; consequently, practices to control the earth proliferated. Mining and refining technologies shifted from a sacred activity to a utilitarian practice. Tools, techniques, and technological systems of delving into the earth

\footnotetext{
${ }^{7}$ Mark Johnson, Metaphors We Live By (Chicago: University of Chicago Press, 1980).

${ }^{8}$ Carolyn Merchant, The Death of Nature (San Francisco: Harper \& Row, 1989).

9 John Locke (1690), The Second Treatise on Civil Government (New York: Prometheus Books, 1986), 19.

${ }^{10}$ Merchant, Death of Nature, 164-190.
} 
and extracting from it carried out this ontology. The "natural environment" was comprised of coordinated and discrete parts, whose pieces could be separated without harm to the whole. The machinery of an inanimate universe was made to align with the gears that the tools, techniques, and technologies required. Social values shifted, driving new technologies, which then drove new or enhanced social values. It is of little consequence now whether this shift was the result of linguistic practice or of the initiation of linguistic change.

Cowan (1997), Johnson (1980), Merchant (1989), and Gould (1996) give us the cognitive tools to understand the motivation behind changes in human action and technology. The reification of qualitative experience, the ranking of quantifications, and the camouflaging of those quantitative determinations' subjective elements, coupled with hierarchical power, domination, and social functionalism, created a formula for technology's objective nature. Functionalism turned both humans and nature into objects of investigation. Political and social scientists, ecologists, environmentalists, and eco-feminists, including Karen Warren (2000), have repeatedly written about this phenomenon in the hopes of rejuvenating the service and respect needed to deal with the problems of class, overpopulation, and environmental pollution. ${ }^{11}$

We must move away from the historical claim that technology is value neutral - such a move leads us to challenge the stronger claim that technology, as a science of machines and a system of organizing the material world, is objective in the same way that mathematics and physical laws are thought to be objective. Numbers and physical laws are tools, yet they emerge and foster thoughts and behavior within a developmental, cultural, and environmental context. Although the valence of technology may be difficult to notice, this does not imply its absence. Technology is not solely the objective practice it presents. Technologies have moral propensities that do not lie solely within the framework of the moral disposition of the user, and while technology does not have moral agency, it has a moral disposition.

\section{Contemporary Examples of Technological Research and Its Interplay with Social Values}

The recognition that technology has a moral disposition without having moral agency is vital to our ethical evaluation of modern technology in the fields of epidemiology, medicine, and DNA research. When we do not recognize these tendencies, we are lulled into the belief that technology provides only a linear, unidirectional movement, out of anyone's control, that is considered to be the nature of progress and the improvement of mankind.

AIDS. In the 1980s, the epidemiology of the AIDS crisis focused on group affiliation (in this instance, gay men) instead of on the individual behaviors that later became the more successful paradigm for analyzing and resisting the disease. Cultural habits, or those systems of thought that directed human behavior (that is, the invisible technology of Neil Postman's work), caused groups of gay men to be singled out, as though the source of the disease lay within this particular population. One could argue that the initial narrow scope of AIDS research was due to the lack of diagnosis among heterosexual populations. Investigations are often begun as a function of visibility and prominence rather than the espoused "valence" issue. However, it took ten more years, while the disease spread epidemically into the heterosexual population, for the technology to reveal inaccuracies in both symptomology and

\footnotetext{
${ }^{11}$ Karen Warren, EcoFeminist Philosophy (New York: Rowman \& Littlefield, 2000).
} 
demographic. Focusing only on what was visible caused a decrease in critical self-awareness and in our awareness of alternatives. This realization that we needed to look at invisible values forced a change in cultural habits, at least in the lab, which then shifted technological focus from specific populations to the specific sexual practices of any one individual. When this occurred, different symptoms were recognized in different groups of men, and in women, for the first time (Rosser 1994). Consequently, different technologies were developed that enabled the identification of different symptoms, specifically in women, and addressed not only the biology of the disease but the sociological and political secrecy around sexual behavior.

The discriminatory values of the culture influenced the development of technologies and practices that then limited the scope of investigation. This limited vision played out by maintaining, enhancing, and confirming those values within the culture until the values did not reflect facts. It is also interesting to note that the research on syphilis that took place in the early twentieth century was initially successful because it did not focus on the cultural taboo of male to male sex as the only loci of symptoms.

Heart disease research. Historically, longitudinal drug studies were performed predominantly on certain classes of white males. What made one eligible for inclusion in these studies was a healthy body, and what constituted a healthy body was a white male body. After a protracted period of incorporating only a small class of white men, rarely even incorporating white women of the same class, social scientists, philosophers, and politicians recognized that these cultural habits infused research technologies with the idea that male bodies were the epitome of "all bodies." Technological research neglected other individuals and groups and caused harm by this neglect. Until quite recently, heart disease in women was rarely diagnosed. Technological tools only focused on the symptoms of compromised large blood vessels; these were the symptoms in the bodies they studied-all men. What we now know is that practice (technology) did not reflect the fact that heart disease manifests itself in the smaller vessels in the bodies of most women. ${ }^{12}$ The technologies were infused with cultural assumptions and were not designed or directed to record different symptoms. Conclusions were drawn based on technologies that stimulated the belief that heart disease killed more men than women. This stimulated further practices (technologies) that better diagnosed heart disease in men by focusing on large blood vessel malfunction and correction. Consequently, women were less often diagnosed as suffering from heart disease, but still continued to die from it.

The valences of technologies designed to diagnose heart disease were directed toward a particular body. The technology directed human thought and action in such a way that, presumably unintentionally, the progress achieved was for the betterment of men, not that of mankind. Yet, as has been suggested, technology does have a propensity to bend behavior in certain directions and not in others, and its direction does not constitute progress for women. The harm done could have been avoided, were the invisible valences made visible.

DNA research. The recent article in Science as Culture by Duana Fullwiley of Harvard, "The Molecularization of Race" (2007), highlights the difficulty in recognizing the invisible within the context of scientific truth. Scientists are trained to believe that our advances are for the objective betterment of mankind, regardless of theoretical science's predisposition

\footnotetext{
${ }^{12}$ Denise Grady, "In Heart Disease, the Focus Shifts to Women," Science Times: New York Times, April 18, 2006, D1.
} 
toward long held discriminatory assumptions about race. Work done in the lab is assumed to be objective and value free; however, some DNA research that is being conducted again establishes a foundational theory of the biological basis of race because it does not recognize the valenced nature of this research. The research does not work objectively to the advantage of all mankind, but rather reflects old discriminatory practices against the people it is meant to help. However, it should be taken into consideration that much of this biomedical research is being conducted to counteract the harm done by years of research that either ignored certain subjects or was performed solely on minorities in an attempt to establish the inferiority of particular races.

Yet in "Is DNA Research Giving New Life to the Idea That Race Exists?", author Ziba Kashef (2007) directs our attention to the part of Fullwiley's 2007 research that focuses on the acceptance of racial categories into the technological applications of funding and reporting results. The historical and cultural practice of normalizing racial categories seems to drive both DNA research being performed by pharmaceutical companies and subsequent technologies that focus on an insignificant percentage of misaligned human genes. "Paradoxically, as the Human Genome Project discredited the use of race in science, the pharmaceutical industry moved in the opposite direction," according to Fullwiley (2007). "Instead of focusing on the $99.9 \%$ overlap in all human genes, the Pharmacogenics Research Network, a government funded follow-up to the Genome Project, honed in on the $0.01 \%$ differences as a source of the new discoveries and therapies."13

A scientist's predisposition to focus on the $0.01 \%$ of nonmatching genes as the biological basis for race, despite their obvious insignificance when compared to the much greater percentage of genes that overlap among all humans, seems to establish the strength of cultural values both in the lab and in the technologies that come out of the lab. Even though current research moves to address different values - after all, bodies are different - the research still shifts to reflect discriminatory values regarding those differences; that is, the differences can be coordinated by racial group rather than by ancestry or geography. Furthermore, research being performed on the small percentage of DNA differences calls these differences significant enough to account for a "racial difference," so that even when minorities are "included" in studies, they are being included as the "left out group," without researchers ever questioning the boundaries of what it means to belong to a particular group.

Some health concerns, such as sickle cell anemia, do show tendencies within particular groups of people; yet, as this example illustrates, many health concerns are being identified as race-based, even though there is little biological evidence to support such claims. As was shown in Troy Duster's analysis of research on the race-based drug BiDil, even though black people aged forty-five to sixty-four are more than twice as likely to die from heart failure than white people of the same age, the disparity narrows after age sixty-five. ${ }^{14}$ The drug research disregards the fact that the disease may have other, overarching causes related to diet, stress, and lifestyle rather than race. The old nineteenth and twentieth century assumptions that race has a biological basis is a fundamental indication of both the invisibility of different cultural and lived practices and the tenacity of those practices that are discriminatory.

\footnotetext{
${ }^{13}$ Ziba Kashef, "Is DNA Research Giving New Life to the Idea That Race Exists?" Color Lines, October 18, 2007, http://www.alternet.org/story/65484 (accessed October 18, 2007).

14 Ibid., 3.
} 
In "The Molecularization of Race" (2007), Duana Fullwiley explains how current DNA technologies reflect and foster the creation, rather than the discovery, of a genetic basis for race by molecularizing race. When the Office of Management and Budget stated in its standards for maintaining, collecting, and presenting data on race (a technological system in and of itself) that their categories reflect a social definition of race and "do not conform to any biological, anthropological, or genetic criteria," the scientists nevertheless "suspended their social experiences and the inscrutability of the categories to comply with larger societal scientific practices of using them to compare US groups." 15 In this research, the social categories of race led to the construction of natural categories of race. "Even when these young researchers' data were 'inconsistent,' potentially providing a space to rethink the assumed group homogeneity inherent in their categorizations, they most often reacted against that data . . . Y Yet, somehow despite their wider social (both local and global) environments, these scientists took the protean to be errors, or contamination, and struggled to fix the race boundaries that were jolted by the appearance of 'inconsistent' DNA frequencies." ${ }^{16}$ In this instance, we are able to see the interdependent relationship between technology and culture where, given past practice and the assumption of technology's value free nature, the research valence would otherwise be invisible.

\section{Conclusion}

The reliance on the objectivity of scientific method actually drives the reinstitution of cultural beliefs regarding the development of both technology and its uses. For example, these cultural beliefs allow the technological molecularization of race to develop, despite competing cultural and scientific evidence. The result is a perpetuation of technology's use in morally controversial manners. Without doubt, morality is culture specific, yet technology crosses cultural boundaries. As we become more sensitive to the cultures in which we wish to incorporate US technologies, political analysts are beginning to investigate whether technologists and researchers have any cognitive notion (moral or otherwise) of the issues associated with technological use in cultures of which they are totally unaware or unexposed. Such an investigation specifically engages the user context of moral deliberation. This article's investigation has focused on the developmental realm, and although the rise of specific technology is cross-cultural, both moral and specific cultural mores are rarely considered and analyzed as part of the developmental context.

The reification of the qualitative dimensions of human life into a more simplified quantitative measure both objectifies human bodies and renders the valenced nature of technologies invisible. We have to recognize that technologies are contextual; biological differences matter, but not necessarily in racialized instances. Even when well-intentioned, if technological production is allowed to remain distant from subjective experience, it will focus only on the mistakes of individuals. DNA research's tendency to molecularize differences camouflages the larger qualitative context of the research. We must be careful that our well-intentioned contemporary efforts to personalize medicine do not stray from the rigor we require of all pursuits of truth, even in the lab. Our analysis of these efforts will be disingenuous if

\footnotetext{
${ }^{15}$ Duana Fullwiley, "The Molecularization of Race: Institutionalizing Human Difference in Pharmacogenetics Practice," Science as Culture (2007): 6, 23. Also see http://www.census.gov/Press-Release/www/2001/raceqandas.html (accessed June 21 2006).

${ }^{16}$ Ibid., 23.
} 
we only look at the user context of this specific kind of DNA research and do not hold young scientists morally accountable for their cultural motivations.

If we evaluate technology in broader contexts, it would not be difficult to notice that the valence of sterilization technology, for example, tends toward the absolute reproductive control of those groups of people that do not fit into the narrow context of what constitutes physical and mental health. We might also notice that the valence of elective cosmetic surgery tends toward Anglo-Caucasian assimilation; that is, noses are reconstructed straighter, dark skin lightened, and Asian eyes rounded. Similarly, the valence of reproductive technology might be - and has been-viewed as tending toward greater control over women under the guise of "more options." Morgan and Lauritzen suggest that reproductive technologies do not increase options but rather limit and coerce options. ${ }^{17}$

Our inability to adequately deal with the developmental, user, environmental, and cultural valences of technology has little to do with the inadequacies of our moral theories. The methods by which we broadly evaluate scientific realms are limited, and so our efforts to address these concerns meet with varying success and are ongoing. We must recognize that the way we construct technology has an influence that is otherwise invisible.

\section{References}

Bush, Corlan Gee. 1983. Women and the Assessment of Technology in Society, Ethics and Technology, ed. Morton E. Winston and Ralph D. Edelbach, 69-83. California: Wadsworth, 2000.

Cowen, Ruth Schwartz. 1997. Industrial Society and Technological Systems in Society, Ethics and Technology, ed. Morton E. Winston and Ralph D. Edelbach, 52-69. California: Wadsworth, 2000.

Dewey, John. 1931. Context and Thought in John Dewey: The Later Works, 1925-1953, ed. Jo Ann Boylston, 6: 3-21. Carbondale and Edwardsville, IL: Southern Illinois University Press, 1981-90.

_ 1927. The Public and Its Problems, 2. Carbondale and Edwardsville, IL: Southern Illinois University Press, 1981-90.

Duster, Troy. 2007. Cited in Ziba Kashef. 2007. Is DNA Research Giving New Life to the Idea That Race Exists? Color Lines, http://www.alternet.org/story/65484 (accessed October 18, 2007).

Ellul, J. 1964. The Technological Society, trans. J. Wilkenson. New York: Knopf.

Fullwiley, Duana. 2007. The Molecularization of Race: Institutionalizing Human Difference in Pharmacogenetics Practice, Science as Culture, 16: 1-30.

Gould, Stephen Jay. 1996. The Mismeasure of Man. New York: W.W. Norton \& Co.

Grady, Denise. 2006. Heart Disease, the Focus Shifts to Women. Science Times: New York Times. April 18. D1.

Johnson, Mark. 1980. Metaphors We Live By. Chicago: University of Chicago Press.

Jonas, Hans. 1974 Technology and Responsibility: Reflections on the New Tasks of Ethics in Society, Ethics and Technology, ed. Morton E. Winston and Ralph D. Edelbach, 114-125. California: Wadsworth, 2000.

Kashef, Ziba. 2007. Is DNA Research Giving New Life to the Idea That Race Exists? Color Lines, http://www.alternet.org/story/65484 (accessed October 18, 2007).

Locke, John. 1690. The Second Treatise on Civil Government. (New York: Prometheus Books, 1986). Lauritzen, Paul. 1993. Commodification and Coercion, Pursuing Parenthood. Indiana U. Press.

Merchant, Carolyn. 1989. The Death of Nature. San Francisco: Harper \& Row.

\footnotetext{
${ }^{17}$ See Kathryn Pauly Morgan, "Women and the Knife: Cosmetic Surgery and the Colonization of Women's Bodies," Hypatia 6 (1991): 25-53; and also see Paul Lauritzen, "Commodification and Coercion," Pursuing Parenthood (Indiana U. Press, 1993).
} 
Morgan, Kathryn Pauly. 1991. Women and the Knife: Cosmetic Surgery and the Colonization of Women's Bodies, Hypatia, 6: 25-53.

Postman, Neil. 1992. Invisible Technologies in Society, Ethics and Technology, ed. Morton E. Winston and Ralph D. Edelbach, 83-93. California: Wadsworth. 2000.

Rosser, Sue. 1994. Women's Health-Missing from U.S. Medicine. Bloomington: Indiana.

Tiles, Mary. 1995. Living in a Technological Culture. London: Rutledge.

Warren, Karen. 2000. EcoFeminist Philosophy. New York: Rowman \& Littlefield.

Winston, Morton E. and Edelbach, Ralph D. eds. 2000. Society, Ethics and Technology. California: Wadsworth.

\section{About the Author}

Dr. Jamie P. Ross

Portland State University, USA 